\title{
Firewood Ash as Calcium Source in the Initial Diet of Broiler Chickens
}

http://dx.doi.org/10.1590/1806-9061-2016-0286

\section{-Author(s)}

\section{Saccomani APO' \\ Faria Filho DE" \\ França XAA"II \\ Dias ANIV \\ Matos Júnior JBV \\ Faria DE"}

Doutoranda em Zootecnia pela Faculdade de Zootecnia e Engenharia de Alimentos (FZEA) da Universidade de São Paulo (USP), Pirassununga, São Paulo, Brasil.

" Docente da FZEA/USP, Pirassununga, São Paulo, Brasil.

III Mestre em Ciências Agrárias pelo Instituto de Ciências Agrárias da Universidade Federal de Minas Gerais, Montes Claros, Minas Gerais, Brasil.

Iv Doutorando em Zootecnia pela Universidade Federal Rural do Rio de Janeiro, Seropédica, Rio de Janeiro, Brasil.

$\checkmark$ Doutor em Zootecnia pela Faculdade de $\mathrm{Ci}$ ências Agrárias e Veterinárias, Universidade Estadual Paulista, Jaboticabal, São Paulo, Brasil.

\section{-Mail Address}

Corresponding author e-mail address Daniel Emygdio de Faria Filho

Avenida Duque de Caxias Norte 255 Campus da USP, Pirassununga, São Paulo, Brasil. CEP 13635-900

Tel: $\quad+55193565-6718$

Email: fariafilho@usp.br

\section{-Keywords}

Alternative feedstuff, bone development calcium source, performance, poultry.

\section{ABSTRACT}

This experiment aimed to evaluate the utilization of firewood ash as calcium source in the initial diet of broiler chickens. One hundred and twenty eight broiler chickens of Cobb-500® strain, from 1 to 21 days of age, were randomly distributed in four treatments with four repetitions of eight birds each, been four female and four male. The experimental diets were corn-soybean based, been isoenergetic and isonutrients, and had 0, 0.32, 0.98 and $1.27 \%$ of firewood ash as calcium source. The firewood ash utilized had $23.8 \%$ of calcium, $0.39 \%$ of total phosphorus, and $0.11 \%$ of sodium. The experimental treatments did not influence the feed intake, body weight, body weight gain, and food conversion from 1 to 7,1 to 14 , and 1 to 21 days of age. The tibia and femur thickness and length at 21 days of age were not altered by treatments. It was concluded that the firewood ash can be used as calcium sourcereplacing limestone in the initial diet of broiler chickens, without change the performance and the bone development.

\section{INTRODUCTION}

Calcium is a macromineral that plays important functions in the body of poultry. It is essential for bone formation and maintenance, blood coagulation, muscle contraction, transmission of nervous stimuli, activation of enzymes in several metabolic pathways, among others (Bertechini, 2013). Approximately 99\% of the calcium in the body is in the bones (Sakomura et al., 2014).

Supplying diets with adequate calcium levels is essential for bone formation to support high growth rates in broilers (Costa et al., 2009). The amount of dietary calcium required to supply the nutritional requirements of high-performance broilers is $0.920 \%$ for 1 - to 7 -day-broilers, $0.841 \%$ for 8 - to 21 -day-broilers, $0.758 \%$ for 22 - to 33 -day-broilers, and $0.663 \%$ for 34 - to 42 -day-old broilers (Rostagno et al., 2011).

Feeds based on vegetable ingredients, such as corn and soybean meal, do not contain sufficient calcium levels to supply broiler nutritional requirements during different rearing phases, and therefore, such diets need to be supplemented with calcium supplementation (Brito et al., 2010). Limestone, containing approximately $37.7 \%$ of calcium, is the main calcium source used poultry diets (Rostagno et al., 2011).

Ashes of the forest biomass, or firewood ash, are solid industrial wastes derived from the combustion of wood and bark to produce thermal energy. It may be employed as a substrate in the production of seedlings because it is rich in minerals, including calcium, which accounts for $25 \%$ of that raw material (Moro \& Gonçalves, 1995).

There are several studies in literature on the calcium requirements of broilers during the starter rearing phase (Alves et al., 2002; Araújo et al., 2002; Sá et al., 2004; Santos et al., 2011; Tancharoenrat \& Ravindran, 
Saccomani APO, Faria Filho DE,

França XAA, Dias AN,

Matos Júnior JB, Faria DE
Firewood Ash as Calcium Source in the Initial Diet of Broiler Chickens
2014), out of which some have evaluated calcium sources, such as calcium carbonate (Alves et al., 2002), calcium citrate-malate (Henry et al., 2002), and calcitic and dolomitic limestone (Sá et al., 2004). On the other hand, to the best of our knowledge, no studies on the use of firewood ash as a calcium source for broilers were published. The objective of this study was to evaluate the inclusion of firewood ash as a calcium source in replacement of limestone in the starter diet on the bone development and performance of broilers.

\section{MATERIALSAND METHODS}

The experiment was performed at the Poultry Sector of the Institute of Agricultural Sciences of the Federal University of de Minas Gerais, Montes Claros, state of Minas Gerais, Brazil. One hundred and twenty-eight one-day-old straight-run (1 male:1 female) Cobb$500 \AA$ broilers, with $47.8 \pm 3.5 \mathrm{~g}$ average body weight, were used. The birds were distributed according to a completely randomized experimental design into four treatments with four replicates of eight broilers each.

Treatments consisted of the dietary inclusion of 0 , $0.32,0.98$, or $1.27 \%$ firewood ash in replacement of limestone. The experimental diets were formulated to contain equal nutrient and energy levels (Table 1). Before

Table1 - Composition of the experimental diets fed during the starter rearing phase (1- to 21-day-old broilers).

\begin{tabular}{|c|c|c|c|c|}
\hline \multirow{2}{*}{ Ingredients } & \multicolumn{4}{|c|}{ Firewood ash (\%) } \\
\hline & 0.00 & 0.32 & 0.98 & 1.27 \\
\hline Corn & 55.39 & 55.39 & 55.39 & 55.39 \\
\hline Soybean meal & 36.24 & 36.24 & 36.24 & 36.24 \\
\hline Soybean oil & 3.52 & 3.52 & 3.52 & 3.52 \\
\hline Dicalcium phosphate & 1.84 & 1.83 & 1.82 & 1.81 \\
\hline DL-methionine & 0.33 & 0.33 & 0.33 & 0.33 \\
\hline Salt & 0.51 & 0.51 & 0.51 & 0.51 \\
\hline Vitamin and mineral premix* & 0.40 & 0.40 & 0.40 & 0.40 \\
\hline Inert material & 1.00 & 0.88 & 0.64 & 0.53 \\
\hline Limestone & 0.77 & 0.58 & 0.17 & 0.00 \\
\hline Firewood ash & 0.00 & 0.32 & 0.98 & 1.27 \\
\hline TOTAL & 100.00 & 100.00 & 100.00 & 100.00 \\
\hline \multicolumn{5}{|l|}{ Calculated composition (as-fed) } \\
\hline Metabolizable energy (kcal/kg) & 3000 & 3000 & 3000 & 3000 \\
\hline Crude protein (\%) & 21.00 & 21.00 & 21.00 & 21.00 \\
\hline Methionine+cystine (\%) & 0.98 & 0.98 & 0.98 & 0.98 \\
\hline Available phosphorus (\%) & 0.45 & 0.45 & 0.45 & 0.45 \\
\hline Calcium (\%) & 0.85 & 0.85 & 0.85 & 0.85 \\
\hline Sodium (\%) & 0.22 & 0.22 & 0.22 & 0.22 \\
\hline
\end{tabular}

* Guaranteed levels per kg of the product: vitamin A 167,000 IU; vitamin D 335,000 IU; vitamin E 2,500 mg; vitamin K 417 mg; vitamin B1 250 mg; vitamin B2 835 mg; vitamin B6 250 mg; vitamin B12 2,000 mcg; folic acid 100 mg; biotin 9 mg; niacin $5,835 \mathrm{mg}$; pantothenic acid 1,870 mg; choline 116,670 mg; copper 1,000 mg; iodine $170 \mathrm{mg}$; iron 8,335 mg; manganese 10,835 mg, zinc 7,500 mg; selenium $35 \mathrm{mg}$; anti-coccidial agent 13,335 mg, performance enhancer $13,335 \mathrm{mg}$; antioxidant 2,000 mg; vehicle qsp 1,000g. the experimental diets were manufactured, firewood ash was analyzed for calcium, total phosphorus, and sodium contents, which were determined as 23.8, 0.39 , and $0.11 \%$ on as-fed basis, respectively.

Broiler chicks were housed in galvanized wire cages (48 cm wide $\times 96 \mathrm{~cm}$ long $\times 33 \mathrm{~cm}$ high), equipped with trough drinkers and feeders. In each cage, chicks were brooded until 14 days old using a 150-watt incandescent lamp. Chicks were vaccinated at the hatchery against Marek's disease and with seven days of age against Newcastle disease and infectious bursal disease. Feed and water were offered ad libitum and 24-h light per day were provided.

Broilers and diets were weighed per cage once a week. On day 21, two broilers per experimental unit were selected and sacrificed by cervical dislocation to remove both right and left tibiae and femora, which thickness and length were measured using a0-150mm digital caliper. Broiler performance (feed intake, body weight, body weight gain, and feed conversion ratio) was evaluated for the periods of 1 to 7,1 to 14 , and 1 to 21 days of age.

Data were verified for the presence of outliers, goodness of fit (Cramér-VonMise test), and variance homogeneity (Brown-Forsythe test), and then submitted to analysis of variance (SAS, 2001).

\section{RESULTS AND DISCUSSION}

Table 2 shows the results of feed intake, body weight, body weight gain, and feed conversion ratio (FCR) for the periods 1 to 7,1 to 14 , and 1 to 21 days of age. The dietary inclusion of firewood ash in replacement of limestone did not affect $(p>0.05)$ broiler performance parameters.

The results of tibial and femoral thickness and length of 21-day-old broilers are presented in Table 3. The inclusion of firewood ash in replacement of limestone did not affect $(p>0.05)$ the bone development of 21-day-old broilers.

Broilers present fast growth rate during the starter phase. In the present study, broiler body weight increased 3.6-, 2.6- and 1.7-foldduring the periods of 1-1, 7-14, and 14-21 days, respectively. Adequate nutritional levels must be supplied to achieve such high weight gain rates. Skeleton development should follow body weight to obtain the best performance. The diet with total replacement of limestone with firewood ash in current study produced similar performance and bone development as the diet with 100\% of limestone as calcium source. This demonstrate the availability of 
Table 2 - Feed intake (FI), body weight (BW), body weight gain (BWG), and feed conversion ratio (FCR) of 1 to 7, 1 to 14 and 1 to 21-day-old broilers fed firewood ash as calcium source.

\begin{tabular}{|c|c|c|c|c|c|c|}
\hline \multirow[b]{2}{*}{1 to 7 days } & \multicolumn{6}{|c|}{ Firewood ash (\%) } \\
\hline & 0 & 0.32 & 0.98 & 1.27 & Prob. & $C V(\%)$ \\
\hline $\mathrm{Fl}(\mathrm{g})$ & $169.2 \pm 10.2$ & $132.5 \pm 11.3$ & $155.0 \pm 15.5$ & $148.4 \pm 7.6$ & 0.60 & 6.38 \\
\hline BW (g) & $176.7 \pm 1.8$ & $165.2 \pm 4.4$ & $170.0 \pm 3.1$ & $173.8 \pm 1.5$ & 0.12 & 2.75 \\
\hline BWG (g) & $129.1 \pm 1.9$ & $117.8 \pm 3.9$ & $122.4 \pm 3.2$ & $126.1 \pm 1.5$ & 0.11 & 3.81 \\
\hline FCR & $1.307 \pm 0.041$ & $1.117 \pm 0.059$ & $1.262 \pm 0.070$ & $1.178 \pm 0.062$ & 0.74 & 6.55 \\
\hline \multicolumn{7}{|l|}{1 to 14 days } \\
\hline $\mathrm{FI}(\mathrm{g})$ & $557.5 \pm 25.4$ & $504.4 \pm 21.9$ & $528.1 \pm 20.6$ & $547.2 \pm 16.4$ & 0.53 & 6.78 \\
\hline BW (g) & $447.9 \pm 5.5$ & $428.8 \pm 13.8$ & $428.1 \pm 12.1$ & $441.9 \pm 6.9$ & 0.44 & 3.99 \\
\hline BWG (g) & $400.3 \pm 5.6$ & $380.9 \pm 13.2$ & $380.5 \pm 12.1$ & $394.2 \pm 5.7$ & 0.43 & 4.45 \\
\hline FCR & $1.392 \pm 0.047$ & $1.322 \pm 0.054$ & $1.388 \pm 0.036$ & $1.387 \pm 0.026$ & 0.69 & 5.16 \\
\hline \multicolumn{7}{|l|}{1 to 21 days } \\
\hline $\mathrm{FI}(\mathrm{g})$ & $1013.3 \pm 10.3$ & $976.3 \pm 12.8$ & $997.2 \pm 8.9$ & $997.2 \pm 5.8$ & 0.31 & 2.02 \\
\hline $\mathrm{BW}(\mathrm{g})$ & $750.0 \pm 2.5$ & $737.5 \pm 12.8$ & $718.6 \pm 8.8$ & $715.6 \pm 3.9$ & 0.24 & 3.16 \\
\hline BWG (g) & $702.4 \pm 2.7$ & $689.7 \pm 8.2$ & $671.0 \pm 8.9$ & $668.0 \pm 4.0$ & 0.24 & 3.35 \\
\hline FCR & $1.443 \pm 0.011$ & $1.415 \pm 0.025$ & $1.489 \pm 0.035$ & $1.493 \pm 0.014$ & 0.21 & 3.13 \\
\hline
\end{tabular}

Mean \pm standard error of the mean. Prob. $=$ probability of analysis of variance. $C V=$ coefficient of variation.

calcium from firewood ash for broilers, i.e., that their metabolism is capable of absorbing and utilizing it to allow bone development compatible with their growth rates of during the starter phase.

Because calcium deposition in the bones is very intense during the grower stage. Calcium body reserves rapidly accumulates during the first phase of life, reaching $80 \%$ of the total body calcium of mature broilers by the end of the first month of age. Inadequate calcium supplementation during early rearing phases causes an imbalance in mineral homeostasis and inadequate bone development. Consequently, bone calcification is abnormal, resulting in skeletal abnormalities (Muniz et al., 2007) and worse performance. Feed intake and performance reductions may indicate slight calcium deficiencies (McDowell, 1992). In the current study, diets with calcium completely derived from limestone or from firewood ash promoted similar bone development and performance, which demonstrates that both calcium sources tested present similar bioavailability.

These results could not be compared with other studies due to the lack of literature on the use of firewood ash as calcium source in animal feeds.

\section{CONCLUSION}

Firewood ash may be employed as a calcium source in replacement of limestone in broiler diets fed during the starter phase ( 1 to 21 days of age), as it promotes similar performance and bone development as limestone.

\section{REFERENCES}

Almeida-Paz ICL, Bruno LDG. Bone mineral density: review. Revista Brasileira de Ciência Avícola 2006;8(2):69-73.

Alves EL, Teixeira AS, Bertechini AG, Rodrigues PB, Oliveira AIG. Efeito dos níveis de cálcio em duas fontes sobre o desempenho de frangos de corte. Ciência e Agrotecnologia 2002;26(6):1305-1312.

Araújo CSS, Artoni SMB, Araújo LF, Borges SA. Avaliação do desempenho e excreção de cálcio em duas linhagens de frangos de corte, na fase inicial, alimentados com diferentes níveis de aminoácidos e de cálcio. Revista Brasileira de Ciência Avícola 2002;4:111-118.

Bertechini AG. Nutrição de monogástricos. 2nd ed. Lavras: Editora UFLA; 2012.

Costa FGP, Brandão PA, Silva JHV, Lima Neto RC, Goulart CC, Pereira WE. Exigências de cálcio para codornas japonesas fêmeas de um a 35 dias de idade. Acta Scientarium Animal Science 2009;31(1):7-12.

Henry MH, Pesti GM. An investigation of calcium citrate-malate as a calcium source for young broiler chicks. Poultry Science 2002;81:1149-1155.

Table 3 - Tibial and femoral thickness and length of 21-day-old broilers fed woodfire ash as calcium source.

\begin{tabular}{|c|c|c|c|c|c|c|}
\hline \multicolumn{7}{|c|}{ Firewood ash (\%) } \\
\hline & 0 & 0.32 & 0.98 & 1.27 & Prob. & $\mathrm{CV}(\%)$ \\
\hline Tibial thickness (mm) & $5.7 \pm 0.1$ & $5.5 \pm 0.1$ & $5.6 \pm 0.2$ & $6.1 \pm 0.1$ & 0.06 & 3.97 \\
\hline Tibial length (mm) & $74.4 \pm 0.8$ & $74.4 \pm 0.4$ & $73.3 \pm 0.8$ & $73.8 \pm 0.6$ & 0.66 & 1.87 \\
\hline Femoral thickness (mm) & $6.5 \pm 0.2$ & $6.3 \pm 0.1$ & $6.4 \pm 0.1$ & $6.8 \pm 0.1$ & 0.09 & 3.62 \\
\hline Femoral length (mm) & $56.1 \pm 0.4$ & $56.0 \pm 0.7$ & $55.4 \pm 0.7$ & $56.1 \pm 0.5$ & 0.83 & 2.14 \\
\hline
\end{tabular}

Mean \pm standard error of the mean. Prob. = probability of analysis of variance. $C V=$ coefficient of variation. 
Saccomani APO, Faria Filho DE, França XAA, Dias AN,

Matos Júnior JB, Faria DE

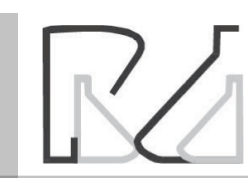

Firewood Ash as Calcium Source in the Initial Diet of Broiler Chickens

frangos de corte, no período de 1 a 21 dias de idade. Revista Brasileira de Zootecnia 2004;33:157-168

Sakomura NK, Vilar-Silva JH, Perazzo-Costa FG, Fernandes JBK, Hauschild L. Nutrição de não-ruminantes. Jaboticabal: FUNEP; 2014.

Santos LM, Rodrigues PB, Freitas RTF, Bertechini AG, Fialho ET, Gomide EM, et al. Níveis de cálcio e fósforo disponível em rações com fitase para frangos de corte nas fases pré-inicial e inicial. Revista Brasileira de Zootecnia 2011;40(11):2476-2485

SAS - Statistical Analysis System Institute. Statistical analysis user's guide. Version 8.2. Cary; 2011

Tancharoenrat P, Ravindran V. Influence of tallow and calcium concentrations on the performance and energy and nutrient utilization in broiler starters. Poultry Science 2014;93:1453-146. 